Toshihiro Yamauchi • Jun Sugimoto

Toyomasa Hatakeyama • Shuichi Asakawa

Nobuyoshi Shimizu • Masaharu Isobe

\title{
Assignment of the human poly(A) polymerase (PAP) gene to chromosome 14q32.1-q32.2 and isolation of a polymorphic CA repeat sequence
}

Received: February 8, 1999 / Accepted: March 26, 1999

\begin{abstract}
We report the chromosomal localization of the gene for human poly $(\mathrm{A})$ polymerase $(P A P)$ and the characterization of a newly isolated $\mathrm{CA}$ repeat near the $P A P$ locus. By fluorescence in situ hybridization and polymerase chain reaction (PCR)-based analysis with both a human/ rodent monochromosomal hybrid cell panel and a radiation hybrid mapping panel, this gene was mapped on the q32.1q32.2 region of chromosome 14. From a genomic clone containing the human $P A P$ locus, we have isolated a polymorphic dinucleotide (CA) sequence. High heterozygosity (0.81) makes this polymorphism a useful marker in the genetic study of disorders localized at the $14 \mathrm{q} 32$ region, such as autosomal recessive congenital microphthalmia (CMIC).
\end{abstract}

Key words Poly A polymerase (PAP) - Chromosome 14q32 - FISH - Radiation hybrid mapping - CA repeat . Congenital microphthalmia (CMIC)

\section{Introduction}

Poly(A) polymerase (PAP) is an enzyme involved in the addition of poly(A) tails to the $3^{\prime}$ ends of eukaryotic mRNA during maturation of mRNA. PAP is involved in several different reactions, including the endoribonucleolytic cleavage reaction and AAUAAA-dependent or -independent adenosine addition (Colgan and Manley 1997). Multiple forms of $P A P$ cDNA have previously been isolated from human (Thuresson et al. 1994), bovine (Raabe et al. 1991; Wahle et al. 1991), mouse (Zhao et al. 1996), and/or frog (Ballantyne et al. 1995) cDNA libraries. The structure of

T. Yamauchi $\cdot$ J. Sugimoto $\cdot$ T. Hatakeyama $\cdot$ M. Isobe $(\square)$ Laboratory of Molecular and Cellular Biology, Department of Materials and Biosystem Engineering, Faculty of Engineering, Toyama University, 3160 Gofuku, Toyama 930-8555, Japan

Tel. +81-764-45-6872; Fax +81-764-45-6874

e-mail: isobe@eng.toyama-u.ac.jp

S. Asakawa $\cdot$ N. Shimizu

Department of Molecular Biology, Keio University School of

Medicine, Tokyo, Japan the gene indicates that different forms of PAP are produced by alternative splicing or by competition between polyadenylation and splicing (Gunderson et al. 1997).

In this study we localized the $P A P$ gene at $14 \mathrm{q} 32.1-\mathrm{q} 32.2$ and isolated a useful dinucleotide repeat polymorphism around this locus.

\section{Results and discussion}

Chromosomal assignment of the human $P A P$ gene was made by polymerase chain reaction (PCR) analysis of a human/ rodent somatic cell hybrid panel and a radiation hybrid panel. The PCR primer sets were designed from the $3^{\prime}$ untranslated region of the human $P A P$ gene (Genbank accession number, I22020). The specific amplified human PCR product was detected only from the hybrid containing human chromosome 14 (Fig. 1a). We performed further mapping analysis using a G3 RH mapping panel with the same primers as those used in the assay for the human/rodent somatic cell hybrid panel. Statistical analysis of the G3 RH mapping data was carried out using the RHMAPPER software package (http://carbon.wi.mit.edu: 8000/cgi-bin/contig/rhmapper.pl). The data for the PAP gene was 00100001001000010000 10011010000001111100011110001000010000101100100110 00110000001011001000001 , and the consequent report indicated that the gene was mapped between markers D14S265 and AFM063XE7, both of which have been cytogenetically mapped to $14 \mathrm{q} 32.1-\mathrm{q} 32.2$. The position of the gene is $0.10 \mathrm{cR}$ from AFM063XE7, with an associated lod score of 2.40 .

To confirm the PCR-based chromosome mapping by an independent approach, we performed fluorescence in situ hybridization (FISH) as previously described (Isobe et al. 1994). With the same primers as those used in the assay for the hybrid panel, we have carried out PCR-based screening of the Keio bacterial artificial chromosome (BAC) library (Asakawa et al. 1997) and isolated a BAC clone $0613 \mathrm{G} 10 \mathrm{~K}$ containing the $P A P$ locus. By using the clone $0613 \mathrm{G} 10 \mathrm{~K}$ as a probe, clear doublet signals were consistently demonstrated at the q32.1q32.2 position of chromosome 14. The typical pattern of the 

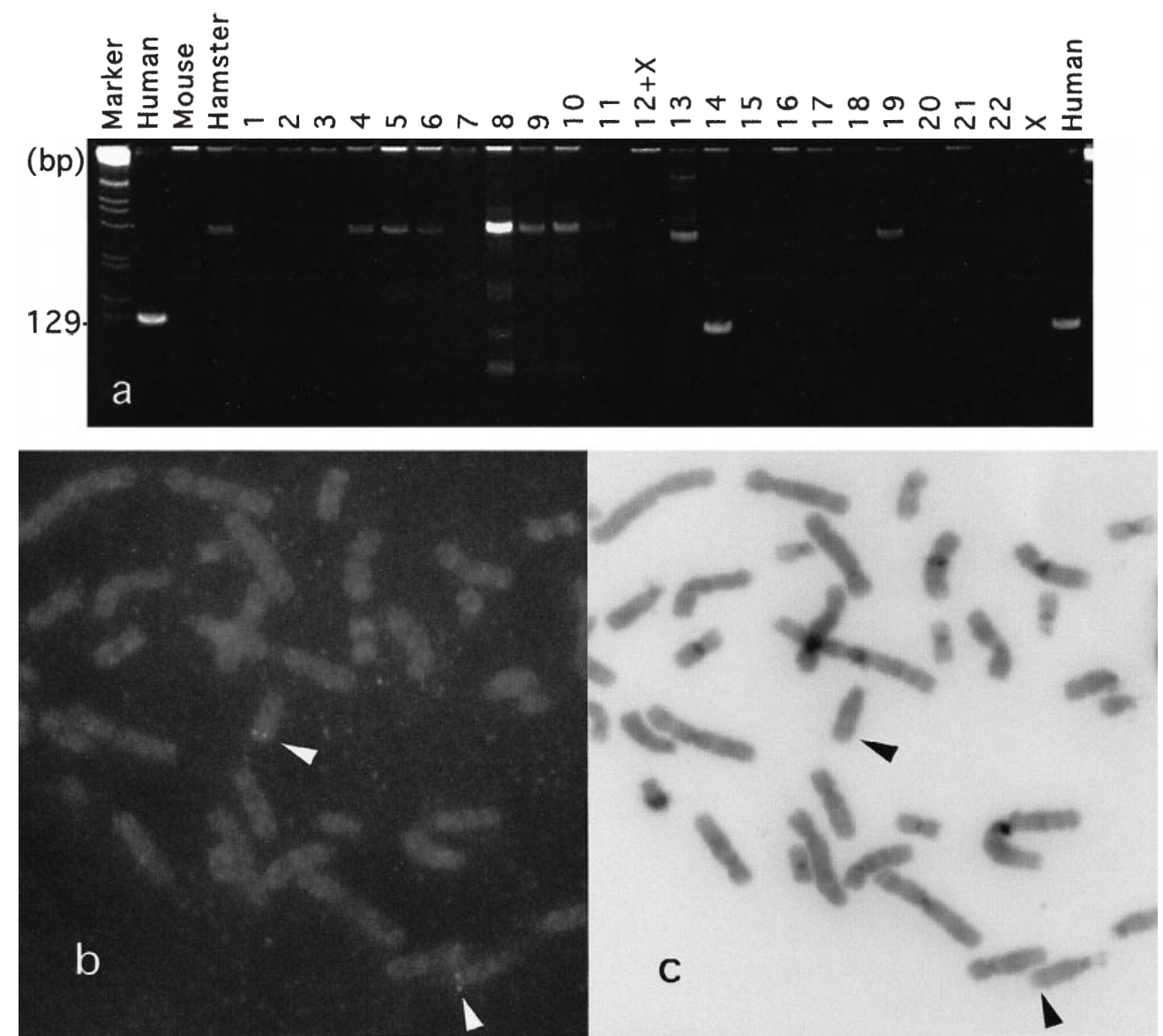

Fig. 1a-c Chromosome mapping of the $P A P$ gene. a Polymerase chain reaction (PCR) analysis of human/rodent hybrid panel. A PCR screening of a human/rodent somatic cell hybrid panel was performed to map the PAP gene to human chromosome 14. A panel of monochromosomal somatic cell hybrids was obtained from the National Institute of General Medical Sciences Human Genetic Mutant Cell Repository (Camden, NJ, USA) and the Japanese Cancer Research Bank. Human, mouse, and Chinese hamster genomic DNAs were also included as control in the assay. Primers used for PCR amplification correspond to $\left(5^{\prime}\right.$ CCCTGAAAAATCTGTAGTTA- $\left.3^{\prime}\right)$ and ( $5^{\prime}$-ATTGGCTATATATT GACATT-3') (PCR product size, $129 \mathrm{bp}$ ). PCR was performed in a volume of $10 \mu \mathrm{l}$, containing $50 \mathrm{ng}$ genomic DNA, $10 \mathrm{mM}$ Tris- $\mathrm{HCl}(\mathrm{pH} 8.3)$,

FISH experiment is represented in Fig. 1b,c. Thus, the gene was judged to map on $14 \mathrm{q} 32.1-\mathrm{q} 32.2$ where the $C M I C$ candidate gene is predicted to lie (Bessant et al. 1998). As a first step to study the relationship between genetic variation at the $P A P$ locus and the genetic backgrounds of this disease, we isolated and characterized a dinucleotide repeat polymorphism around the $P A P$ locus. A fragment containing a CA repeat, identified by Southern blot hybridization of BAC DNA doubly digested by EcoRI and HindIII with a $(\mathrm{CA})_{20}$ probe, was subcloned and sequenced (DDBJ accession number, AB025574. PCR primers $0613 \mathrm{CA}$ 55E/H-272U (5'-GGGAGTAAGGTGATCTCTGT-3') and 0613 CA E/H-538L (5'-CGCAAACAAGGACCAATCT-3') were designed to flank this new repeat sequence for polymorphic analysis. PCR was performed in a volume of $10 \mu \mathrm{l}$ containing $50 \mathrm{ng}$ genomic DNA, $10 \mathrm{mM}$ Tris $\mathrm{HCl}(\mathrm{pH} 8.3), 10 \mathrm{mM}$ $\mathrm{KCl}, 4 \mathrm{mM} \mathrm{MgCl} 2,125 \mu \mathrm{M}$ dNTPs, 1 pmol of a fluorescencelabeled forward primer, $1 \mathrm{pmol}$ of non-fluorescence-labeled
$10 \mathrm{mM} \mathrm{KCl}, 4 \mathrm{mM} \mathrm{MgCl} 2,125 \mu \mathrm{M}$ each of dNTPs, 2 pmol of each primer, and $0.25 \mathrm{U}$ of Taq polymerase. Cycle conditions were $94^{\circ} \mathrm{C}$ for $3 \mathrm{~min}$, then 35 cycles of $94^{\circ} \mathrm{C}$ for $40 \mathrm{~s}, 45^{\circ} \mathrm{C}$ for $1 \mathrm{~min}$, and $72^{\circ} \mathrm{C}$ for $2 \mathrm{~min}$, with a final extension step of $3 \mathrm{~min}$ at $72^{\circ} \mathrm{C}$ in an Omni Gene thermal cycler (Hybaid). Numbers at the top of each lane indicate the human chromosome contained in each somatic cell hybrid. b Fluorescence in situ hybridization (FISH) of the PAP gene. The specific labeling was observed at 14q32.1$\mathrm{q} 32.2$, as indicated by white arrow heads. c The image of 49, 6-diamidino-2phenylindole dihydrochloride (DAPI) stained chromosomes was inverted by using IPLab software (Photometrics, Tacson, AZ, USA) to obtain a pseudopositive G-banding pattern. The chromosome 14 homologs are identified with black arrow heads

reverse primer, and 0.3 units of Taq polymerase. The cycle conditions were $94^{\circ} \mathrm{C}$ for $3 \mathrm{~min}$, then 30 cycles of $94^{\circ} \mathrm{C}$ for $30 \mathrm{~s}$, $50^{\circ} \mathrm{C}$ for $1 \mathrm{~min}$, and $72^{\circ} \mathrm{C}$ for $2 \mathrm{~min}$, in an Omni Gene thermal cycler (Hybaid, Middlesex, England). The PCR products were electrophoresed in 0.25 -mm-thick denaturing $4 \%$ polyacrylamide gel at $1500 \mathrm{~V}$ for $6 \mathrm{~h}$, using an automated DNA sequencing machine (IR4000; LI-COR, Lincoln, NE, USA). The sizes of alleles were determined by comparison with the sequencing ladder of a control plasmid. Eight alleles were detected in 134 chromosomes of DNA from a Center d'Etude du Polymorphisme Humain (CEPH) family. Codominant inheritance was observed in two three-generation families. The size and frequency of the eight alleles are shown in Table 1, with the observed heterozygosity of 0.81 . This highly informative polymorphic marker may provide a clue to look for the disease-related genes around this locus. 
Table 1. Size and frequency of the alleles of the CA repeat polymorphism around the PAP locus

\begin{tabular}{lll}
\hline Allele & Size (bp) & Frequency \\
\hline A1 & 298 & 0.05 \\
A2 & 296 & 0.01 \\
A3 & 294 & 0.15 \\
A4 & 292 & 0.02 \\
A5 & 290 & 0.13 \\
A6 & 288 & 0.38 \\
A7 & 286 & 0.15 \\
A8 & 278 & 0.11 \\
\hline
\end{tabular}

Acknowledgments This work was supported in part by a Grant-in Aid from the Ministry of Education, Science, Sports and Culture of Japan and by a Grant from the Human Frontier Science Program.

\section{References}

Asakawa S, Abe I, Kudoh Y, Kishi N, Wang Y, Kubota R, Kudoh J, Kawasaki K, Minoshima S, Shimizu N (1997) Human BAC library: construction and rapid screening. Gene 191:69-79
Ballantyne S, Bilger A, Astrom J, Virtanen A, Wickens M (1995) Poly (A) polymerases in the nucleus and cytoplasm of frog oocytes: dynamic changes during oocyte maturation and early development. RNA 1:64-78 Bessant DA, Khaliq S, Hameed A, Anwar K, Mehdi SQ, Payne AM, Bhattacharya SS (1998) A locus for autosomal recessive congenital microphthalmia maps to chromosome 14q32. Am J Hum Genet 62:1113-1116

Colgan DF, Manley JL (1997) Mechanism and regulation of mRNA polyadenylation. Genes Dev 11:2755-2766

Gunderson SI, Vagner S, Polycarpou-Schwarz M, Mattaj IW (1997) Involvement of the carboxyl terminus of vertebrate poly(A) polymerase in U1A autoregulation and in the coupling of splicing and polyadenylation. Genes Dev 11:761-773

Isobe M, Koyata H, Sakakibara T, Momoi-Isobe K, Hiraga K (1994) Assignment of the true and processed genes for human glycine decarboxylase to 9p23-24 and 4q12. Biochem Biophys Res Commun 203:1483-1487

Raabe T, Bollum FJ, Manley JL (1991) Primary structure and expression of bovine poly(A) polymerase. Nature 353:229-234

Thuresson AC, Åström J, Åström A, Grönvik KO, Virtanen A (1994) Multiple forms of poly(A) polymerases in human cells. Proc Natl Acad Sci USA 91:979-983

Wahle E, Martin G, Schiltz E, Keller W (1991) Isolation and expression of cDNA clones encoding mammalian poly(A) polymerase. EMBO J 10:4251-4257

Zhao W, Manley JL (1996) Complex alternative RNA processing generates an unexpected diversity of poly(A) polymerase isoforms. Mol Cell Biol 16:2378-2386 